\title{
THE DIFFERING FEDERALISMS OF CANADA AND THE UNITED STATES
}

\author{
Martha A. Field* \\ I \\ INTRODUCTION
}

There are some remarkable differences in the ways that Canada and the United States have structured their federalisms-differences that teach us not only about the two systems involved but also about the possibilities of federalism generally. The aim of this article is to provide an overview of this subject for the reader who is new to it. It will compare the role of the provinces and the role of the states in the federal schemes of Canada and the United States and will survey three main subjects:

1. the scope of the central government's legislative power in the United States and Canadian systems;

2. the relationship between federal and provincial or state law; and

3. some of the differences in national judicial power between our systems. This topic illustrates, among other things, the Canadian approach of negotiation between the branches-and between central and provincial spheres-in comparison with the United States's more legalistic approach and somewhat clearer separation of powers and functions.

\section{II}

The Distribution of Legislative Power between the Two LEVELS OF GOVERNMENT

One remarkable truth of the Canadian and United States federalisms is that each country has departed from the original understanding of the distribution of federal power as expressed in the Constitution. In both cases, the departure has been accomplished primarily by judicial interpretation by the nation's highest court. An irony, however, is that each system has evolved to be more like the plan for the other: In Canada, the intent, clearly reflected in the Constitution of 1867 , was for the central government to predominate, but the Judicial Committee of the Privy Council (which was the ultimate judicial authority until 1949, when that position was inherited by the Supreme Court of Canada) interpreted provincial powers generously and federal powers with restraint, giving the provinces a much greater share in the 
balance of power than had been contemplated. ${ }^{1}$ The United States has moved in the opposite direction; here the constitutional plan was one of states' rights, but the result has been strong central government.

The degree of central government power is not the only difference between the systems. If anyone ever entertained the notion that there was a "normal" way for federalism to be structured, a comparison of the distribution of legislative power in the United States and Canada would dispel that notion. On one level, there are noticeable differences in where particular powers are lodged. Marriage and divorce and criminal law, for example, are governed by the central government in Canada but the state governments in the United States, while labor law, nationalized in the United States, is an area jealously guarded by Canada's provincial governments. Moreover, Canadian provinces have much more exclusive power over local commerce than U.S. states do. The central government in Canada does not have effective power to impose economic plans and solutions without the participation and assent of the provinces. The U.S. Congress, by comparison, has authority to regulate essentially all economic activity.

Even more basic than the different distribution of particular powers are the structural differences between the systems. In Canada, the federal and provincial governments are each assigned certain categories of legislation, to the exclusion of the other. ${ }^{2}$ If the government to which the subject has been

1. The result was so counter to the original intention that an apochryphal story about the Attorney General of the Southern Confederacy, after its defeat, going to England and there winning the ear of the Privy Council for the "states' rights" cause, is a familiar way of explaining it. It is true that Judah Benjamin, who had been Attorney General of the Confederacy, went to London after the fall of the Confederacy and became prominent in the London Bar, but it is not certain that during the last 20 years of the nineteenth century he really exercised the influence over the Privy Council that is claimed for him.

For whatever reason, however, the Privy Council did depart from the Framers' conception of the proper balance between the center and the provinces. The Canadian Constitution of 1867 profited from its southern neighbor's example of a federal system and also, adopted in the aftermath of the U.S. Civil War, sought to avoid what was perceived as the mistakes of strong states' rights and the centrifugal force that had led to the U.S. Civil War. As Chief Justice Ritchie said,

[by] the constitution of the Dominion ... the legislative power of the Local Assemblies, is limited and confined to the subjects specifically assigned to them, while all other legislative powers, including what is specially assigned to the Dominion Parliament, is conferred on that Parliament; differing in this respect entirely from the constitution of the United States of America, under which the State Legislatures retained all the powers of legislation which were not expressly taken away.

Valin v Langlois, [1880] 3 SCR 1, 14 (Ritchie) (emphasis in original). Despite this intent, the Privy Council interpreted national power narrowly:

[T] he exercise of legislative power by the Parliament of Canada, in regard to all matters not enumerated in section 91 , ought to be strictly confined to such matters as are unquestionably of Canadian interest and importance, and ought not to trench upon provincial legislation with respect to any of the classes of subjects enumerated in section 92. To attach any other construction to the general power which, in supplement of its enumerated powers, is conferred upon the Parliament of Canada by section 91, would, in their Lordships' opinion, not only be contrary to the intendment of the Act, but would practically destroy the autonomy of the provinces.

Local Prohibition Case, [1896] AC 348, 360-61 (PC).

2. The central government in Canada was given important enumerated powers as well as the residuary power (unlike the U.S. states, which was given only residuary power). In $\$ 91$-the main section giving legislative power to the Parliament-29 enumerated powers are listed, and it is then 
entrusted does not act, therefore, the subject goes unregulated. In the United States, by contrast, the norm is that the nonexercise of federal power to regulate increases the area for state regulation; there are few if any separate spheres in which it is constitutionally permissible only for states to regulate.

This situation of no separate sphere for state lawmaking evolved in part because the states were not given specific powers in the U.S. Constitution, but were left the residuary power. The scheme was that the federal government would have limited and specified powers and all the other powers would belong to the states. In the Canadian Constitution, the scheme was the opposite: the central government would have the residuary as well as specific powers, and the provincial governments' power was to be limited and specified.

In both countries the intent was that the government with the residual power would play the stronger role. The framers of the U.S. Constitution intended federal law to be supreme, but they also assumed that the subject matter of federal law would be limited, so that the residuary clause- "The powers not delegated to the United States by the Constitution, nor prohibited by it to the States, are reserved to the States respectively, or to the people"3 would have some content. The general lawmaking power thus retained by states, including the basic police power functions of government, were thought to have some significant scope. But because in the U.S. governmental structure the tenth amendment was only a truism, ${ }^{4}$ granting to states only whatever power was not possessed by the federal government, expansions of federal power ipso facto cut down on what was reserved to the states. Eventually, federal powers in the United States were interpreted so broadly that little or nothing remained of the residuum.

The obvious example of broad interpretation of a federal power having this effect is the commerce clause, giving Congress power to regulate interstate commerce. The clause has been read to allow Congress to regulate any activity that could have any impact at all on interstate commerce, leaving Congress free to regulate any economic activity it wishes and displacing any separate sphere for state legislative control of the economy. The framers

provided that "any Matter coming within any of the Classes of Subjects enumerated in this Section shall not be deemed to come within the Class of Matters of a local or private Nature . . assigned exclusively to the Legislatures of the Provinces [set out in \$ 92]." The residuary clause provides,

It shall be lawful for the Queen, by and with the Advice and Consent of the Senate and House of Commons, to make Laws for the Peace, Order, and good Government of Canada, in relation to all Matters not coming within the Classes of Subjects by this Act assigned Id. exclusively to the Legislatures of the Provinces . . . .

Section 91 also spells out that the enumerated powers should not be deemed to limit or detract from this broad power. The grant of residuary power-known as the peace, order, and good government provision ("POGG")-appears to grant the central government something like what is called the "police power" in the United States-- the power to legislate generally for the public health, safety, welfare, and morals, a power associated with the states in the United States.

3. US Const, Amend X.

4. See United Stales v Darby, 312 US 100, 124 (1941) ("The [tenth] amendment states but a truism that all is retained which has not been surrendered."). 
could not have foreseen the extent to which Congress would be empowered to control the economy.

In Canada, by contrast, the clause giving the central government control over trade and commerce has been interpreted to allow regulation of only international or interprovincial trade. That narrow interpretation of the commerce power is part of a more general cutback on the powers of the central government. ${ }^{5}$ Other legislative powers, most notably the power of the central government "to make laws for the Peace, Order and good Government of Canada" ('POGG'), were also narrowly read-artificially narrowly, and certainly more narrowly than the original framers had intended. ${ }^{6}$ Indeed, the experiences of both nations attest to the relative unimportance of both constitutional language and framers' intent in determining results.

The scheme resulting in the United States is considered to leave states very weak-to a point where some say we do not even have a viable form of federalism. ${ }^{7}$ I want to explore this position for a moment because constitutional scholars are engaged in a debate about whether it is true,$^{8}$ and a comparison of the U.S. states with Canada's provinces throws light on it.

The perceived problem is that in the United States it is only by default of Congress that states are left with areas in which state laws can operate. In retrospect, a structure like that of the Canadian government, which reserves explicit powers at both the central and provincial levels, might have better protected the states' rights that the framers envisioned. As it has developed,

5. The Canadian provinces have much more control over local commerce as part of their broadly-interpreted exclusive legislative powers over "Property and Civil Rights in the Province" and "Generally all Matters of a merely local or private Nature in the Province." $\$ 92$ (13), (16). This local control has been found to exist even though one of the enumerated powers of the central legislature set out in $\S 91$ is "The Regulation of Trade and Commerce" and despite the rules of liberal construction of central government powers set out in $\$ 91$ and described in note 2.

6. Of course, the central government is by no means powerless. Not all provisions have been read as narrowly as the commerce power and the POGG clause have. The spending clause in Canada, as in the United States, has been an avenue for centralization, and cost-sharing programs have allowed for central government influence even over areas the Constitution leaves exclusively to the provinces. Moreover, as Katherine Swinton discusses in her interesting article, the courts have accepted an emergency theory of the POGG provision, allowing the national legislature to use that provision broadly when enacting temporary legislation that might be thought necessitated by an emergency or crisis. See Katherine Swinton, Federalism under Fire: The Role of the Supreme Court of Canada, 55 L \& Contemp Probs 121, 126 (Winter 1992). Nonetheless, the general situation in Canada remains one of strong provincial legislatures and, accordingly, dual sovereignty.

7. The most articulate spokesperson for this position is Professor William W. Van Alstyne. See, for example, William W. Van Alstyne, The Second Death of Federalism, 83 Mich L Rev 1709 (1985); William W. Van Alstyne, Dual Sovereignty, Federalism and National Criminal Law: Modernist Constitutional Doctrine and the Nonrole of the Supreme Court, 26 Am Crim L Rev 1740 (1989). See also Philip B. Kurland, Politics, the Constitution, and the Warren Court 54-57, 96 (U Chicago Press, 1970) ("Federalism is dead.").

8. For example, Professor Jesse Choper disagrees with Professor Van Alstyne's position and asserts that is it appropriate that neither federalism nor separation of powers be judicially enforced when individual rights are not at stake. See generally Jesse $\mathbf{H}$. Choper, Judicial Revieu and the National Political Process: A Functional Reconsideration of the Role of the Supreme Court (U Chicago Press, 1980). I have also taken a position contrary to Professor Van Alstyne. See, for example, Martha A. Field, Garcia v. San Antonio Metropolitan Transit Authority: The Demise of a Misguided Doctrine, 99 Harv L Rev 84 (1985). 
however, there is little or no separate sphere of activity that can be regulated only by states in the U.S. constitutional system. Or, more accurately, the U.S. Congress decides for itself what it shall regulate and what it shall leave to state regulation.

The criticism of judicial abdication is that courts have not limited congressional power and have not carved out subject matter areas into which Congress cannot enter. From this perspective, the issue becomes one of separation of powers between legislative and judicial branches as much as an issue of federalism. While some contend that U.S. courts have abdicated to Congress the courts' function in deciding issues of federalism, others claim per contra that the issue of what should best be left to the federal government and what to the state governments is as appropriately decided by Congress as the courts.

It has been hotly and repeatedly contested in the Supreme Court whether there is any sphere that is immune from federal preemption and regulation, if Congress chooses to act. The U.S. Supreme Court has wavered on this question to some extent, ${ }^{9}$ but the current law is that the tenth amendment is indeed a truism and that there is no separate state sphere. ${ }^{10} \mathrm{~A}$ majority of the U.S. Supreme Court has explained, however, that it is appropriate for Congress to decide which areas should be left for state regulation, and that judicial oversight is not necessary because the states themselves are represented in Congress." In some sense, Congress's decisions about the

9. Even in very recent history, there has been some pendulum swing between one position and the other. For example, in Maryland $v$ Wirtz, 392 US 183 (1968), the Supreme Court held that state sovereignty does not restrict Congress from exercising its powers under the commerce clause and that there is no principle requiring that Congress yield to states in the performance of their governmental functions. Justice Harlan wrote the opinion for the Court, and there were two dissenters. Eight years later, the Supreme Court reversed course, holding in National League of Cities $v$ Usery, 426 US 833 (1976), that there were some regulations within the commerce clause that Congress nonetheless could not constitutionally impose upon the "States as States." Because of this, the Court invalidated the extension of federal minimum wage and maximum hours legislation to state employees. Control of state employees was "essential to [the] separate and independent existence" of the states, and for that reason Congress could not impose the regulations, although they were otherwise within the federal commerce power. Id at 845-52. Four justices dissented from the National League of Cities holding, and in the nine years that the holding remained law, the Court never found another state immunity, even in some situations closely analogous to National League of Cities. See, for example, EEOC v Wyoming, 460 US 226 (1983). Then, in Garcia v San Antonio Metropolitan Transit Authority, 469 US 520 (1985), the Court reversed course again, holding that the tenth amendment has no affirmative thrust and that National League of Cities had erred by "underestimat[ing] . . . the solicitude of the national political process for the continued vitality of the States." Id at 557. Again there were four dissenters, and they looked forward to prevailing at a future date. Id at 580 (Rehnquist); id at 589 (O'Connor).

10. Garcia, 469 US 528.

11. See id at 551. The leading academic exposition of this position is found in Herbert Wechsler, The Political Safeguards of Federalism: The Role of the States in the Composition and Selection of the National Government, 54 Colum L Rev 543, 558-60 (1954). See also Field, 99 Harv L Rev at 106-10 (cited in note 8); Choper, Judicial Review and the National Political Process (cited in note 8).

It is interesting to note that this argument concerning representation in the national legislature has no counterpart in Canada's Parliament, because provincial "representatives" are appointed by the central authority. Indeed it is the Supreme Court of Canada that has some of the representative capacity reflected in the U.S. Senate and missing from the Canadian Parliament. The Supreme Court includes three justices from Ontario, three from Quebec, two from the provinces in the West, and 
reach of federal power are the decision of the states, or at least are approved by the states as a body. The constitutional scheme accordingly entrusts to Congress decisions about the reach of federal power vis-vis state power, rather than entrusting it to the judiciary or creating predefined subject matter limits.

The Supreme Court has also said, however, that there is some limit on what Congress can do; the judiciary will step in to ensure that our system of federalism continues-to ensure that the states are allowed to retain a separate significance. ${ }^{12}$ The decision of which powers the federal government should exercise is better made by Congress than the courts, and hence is entrusted to Congress, but it is subject to judicial review at the extremes. Congress cannot constitutionally so disempower the states as to effectively dismantle the federal system.

If this is the limit to which Congress must adhere in order to satisfy the minimal demands of a federal system, Congress has not come close to the line. Although the areas in which state law will operate are not preordained by the Constitution, state law is the operative force in many important areas of life: family law, criminal law, real estate, trusts and estates, zoning, professional licensing, motor vehicle regulation, and education, to name a few.

Nonetheless, the absence of any constitutionally mandated separate sphere for state lawmaking makes the U.S. states look significantly less powerful than their provincial counterparts. Although that is the popular view of this subject, a further comparison of Canadian and United States federalism may cast light upon whether this view is entirely accurate.

III

\section{The Relationship between Federal and Provincial or State Law}

In the United States, the Constitution does not define the areas in which state law can operate; instead, it leaves that decision to be made primarily by Congress. While in comparison to the Canadian provinces the states are weak vis-vis the national legislature (except for their representation there), they are more insulated from national control in other ways. There is no predefined area in which state law can operate in the United States, but when

one from the Atlantic provinces. Moreover, when cases involve particular provinces or regions, the panel that decides the case is selected so that it will include the representatives of that region. In that sense, the Canadian Supreme Court is more representative than the U.S. Supreme Court, where regional considerations are relevant to appointments, but to a far lesser degree. Even though it is geographically representative, the Canadian Court is not really analogous to the U.S. Congress, because the Canadian "representatives" of the various regions are neither elected nor chosen by persons from their own region.

12. Garcia, 469 US at 556. See also Fry $v$ United States, 421 US 542, $547 \mathrm{n} 7$ (1975); Field, 99 Harv L Rev at 110-15 (cited in note 8). To this limited extent, it is not strictly accurate to say, as a Canadian scholar has, that the "federal system in the United States exists only on congressional sufferance." Alexander Smith, The Commerce Power in Canada and the linited States 371 (Butterworks, 1963). 
it does operate, it is more autonomous and has more independent force than provincial law does in Canada.

In the United States, national courts sometimes apply state law, but they never claim to be its interpreter. State law is, by definition, what that state's supreme court says it is. However unreasonable a state's reading of its own law may appear to the U.S. Supreme Court, that law nonetheless governs unless the U.S. Supreme Court holds that the law, so interpreted, violates the U.S. Constitution.

The position that state courts are the final arbiters of the meaning of state law was adopted in this country in Memphis $v$. Murdock, decided in 1875.13 Although the result was not required by the Constitution, and also flew in the face of the intent Congress appeared to express in the statute granting jurisdiction to the Supreme Court, ${ }^{14}$ Murdock's approach has remained in effect to the present and indeed is deemed one of the cornerstones of the federal system. Each year I discuss with law students whether the Supreme Court was warranted in imposing this system despite the apparent lack of legal justification, and the consensus often is that the rule that state courts are the arbiters of the meaning of state law seems necessary. Otherwise, how could the states have any control over the development of their own law? Indeed, what would the phrase "state law" even mean if the states were not to have the last word on what the law of the state is? 15

Here again the Canadian system illustrates that the United States's ways of doing things are not the inevitable ones. Nor are they the only workable ones. Canada has a system of provincial courts, which are in fact the primary courts in Canada. When it reviews their decisions, however, the Canadian Supreme Court has the final word in deciding issues of common law and also in interpreting provincial enactments. Provincial law is not separated from national law or from the input of national judicial decisionmakers in the same way state law is in the United States.

The United States system goes even beyond Murdock. In the even more famous Erie R.R. v. Tompkins, ${ }^{16}$ the Supreme Court ruled that lower federal court judges faced with state common law issues should not fathom their own solutions but should follow decisions of the supreme court of the relevant state. The concept behind Erie was the same as Murdock's-that to have control over their own law, state courts, and not federal, must be the authority concerning the law's meaning.

The Canadian system of allowing federal judicial input into the meaning of provincial law is something like the system that Erie overruled, the system we associate with Swift $v$. Tyson. ${ }^{17}$ Swift set out the pre-Erie system wherein federal

13. 87 US (20 Wallace) 590 (1875).

14. See the discussion in Martha A. Field, Sources of Law: The Scope of Federal Common Law, 99 Harv L Rev 881, 920-22 nn180 \& 181 (1986).

15. Id at $921-22 \mathrm{nl} 82$.

16. 304 US 64 (1938).

17. 41 US (16 Peters) l (1842). 
judges decided for themselves state common law issues, partly because common law was seen as a brooding omnipresence containing one right answer to any question that each judge, state or federal, could independently strive to discover. Even under Swift v. Tyson, however, state statutes were exempt from federal judicial input, and state common law relating to real estate and other immovables was also exempt.

In short, while the Canadian model recognizes much more of a separate and exclusive legislative sphere for provincial lawmaking than the U.S. model does for the states, it does not grant as much independence to the provincial law that is thus made; Canada has more centralized judicial control of provincial law, and provincial courts have less of a separate sphere than provincial legislatures do, or than the state judicial system does in the United States.

This may tell us something about federalism. It certainly suggests that there are varied ways for the different levels of government, which are the essence of federalism, to maintain their significance. It may be that one reason Canada does not need a separate, more independent provincial law is that the Canadian Constitution leaves for provinces important spheres of activity in which only provincial law can operate. Maybe as long as a nation has one of these forms of strong state or provincial power, it does not need others for there to be a strong intergovernmental relationship-strong enough to satisfy the demands of a viable federalism. Even powers as basic as a separate sphere of legislative competence or the ability to interpret one's own laws are not necessary in order for governments to retain significance if governments have other important powers.

The U.S. states and the Canadian provinces achieve their power through different mechanisms. In the United States, states remain significant units of government because they have the significant power of a separate and independent state law over which the state has the final word. ${ }^{18}$ Moreover, there is a large area in which state law operates, although the area is not predefined or protected from possible future congressional encroachment.

IV

Some Comparisons between the Canadian and U.S. Judicial Systems

I want to compare the experience of our two nations concerning the judicial branch of government, and then to examine a few of the themes that pervade the Canadian system and that seem to distinguish it from that of the United States.

There are many levels on which to compare our court systems. In both systems, the Supreme Court has jurisdiction to review decisions coming from both state and federal courts, and has the power and duty-unusual even in

18. State law is subject to federal constitutional law, and in that sense is within the control of the federal judiciary, but unless the state law is held unconstitutional, the state, through its legislature, courts, or other agencies, can define what the law is and what it means. 
countries that have constitutions-to depart from legislation that does not conform to the national constitution. ${ }^{19}$ Although the federal courts in Canada have been increasing in number and importance, they are not as important as the U.S. federal courts, and they also are not nearly as important as the provincial courts, which are empowered to decide all legal questions. Canada's federal courts, by contrast, do not have pendent and ancillary jurisdiction over issues governed by provincial law, so a litigant who wants a controversy decided in one tribunal instead of two must present the controversy to a provincial rather than a federal court. ${ }^{20}$

Distinctions are often drawn between the Canadian and U.S. judicial systems on the basis of judicial activism; the U.S. system is said to be significantly more activist than the Canadian. It is worth noting, however, that there are ways in which the Canadian judicial system is more assertive than the United States's. The example we have already seen is that the Canadian judiciary exerts control to keep each legislature, national as well as provincial, within its proper bounds, while in the United States the Court largely leaves to Congress decisions about how much to intrude upon what has been the states' legislative turf. There are other examples as well. For one, Canadian courts reviewing the constitutionality of a challenged legislative enactment have the duty to examine the purpose and effect of the law and to uphold it only if "the pith and substance" of the enactment is within the jurisdiction of the enacting legislature. U.S. courts, by contrast, in most instances must accept legislation at face value and not question its legitimacy if there is any reasonable basis for upholding it. ${ }^{21}$ In this respect, at least, Canadian

19. Section 52 of the $\mathbf{1 9 8 2}$ Charter provides that Canada's Constitution "is the supreme law of Canada, and any law that is inconsistent with the provisions of the Constitution is, to the extent of the inconsistency, of no force or effect." The common law doctrine of federal paramountcy, see Peter W. Hogg, Constitutional Law of Canada 353-67 (Carswell, 2d ed 1985), is similar (and similar to the U.S. Constitution's supremacy clause), and provisions such as $\S 15$ of the Charter of Rights, applicable since 1985, contemplate an active role for the judiciary in policing the legitimacy of provincial and central government measures.

In the United States, the Constitition explicitly provides for supremacy of federal over state law, and judicial supremacy was declared to exist in Marbury $v$ Madison, 5 US (1 Cranch) 137 (1803). Though scholars disagree about whether that holding was justified at the time on the basis of existing constitutional language or intent, it has become an accepted cornerstone of the U.S. system.

20. See generally, Peter W. Hogg, Federalism and the Jurisdiction of Canadian Courts, $30 \mathrm{U}$ New Brunswick L J 9 (1981).

21. Professor Harvey Wingo considers the abandonment of such a doctrine in the United States the most significant factor in "the collapse of true federalism in the United States." See Harvey Wingo, U.S. and Canadian Federalism: A Study in Contrast, 11 Vt L Rev 473, 476 (1986). During the 1920 s and until 1937, the Supreme Court of the United States similarly examined legislative motivation, and an early and famous case, McCulloch v Maryland, 17 US (4 Wheaton) 316 (1819), provided authority for it to do so. McCulloch is known for recognizing broad powers in Congressrecognizing implied powers and also broadly interpreting the necessary and proper clause-but it also limited congressional powers, articulating the doctrine that Congress could only permissibly regulate for a legitimate end, that is, an end within its own delegated powers. Since 1937, however, it has been clear that federal courts will not examine Congress's true purposes or motivation in enacting a particular law. The Supreme Court will uphold legislation if it could rationally be thought to promote legitimate ends, even though all know that those ends are not the purpose the legislation was designed to serve. Thus Congress can regulate civil rights or morality by use of the commerce power, for example. Wingo believes that the reason for the "death of federalism" in the United States is the Court's refusal to examine whether Congress is using its grant of power as a pretext for 
doctrine is more encouraging of courts' second-guessing legislatures. In some other ways, the Canadian Constitution gives the judiciary broad powers of decisionmaking (for example, the 1982 Charter's endorsement of affirmative action). ${ }^{22}$ Moreover, the enactment of the Charter, authorizing for the first time judicial review of legislation for violation of constitutionally protected individual rights, represents a relatively recent but extremely significant increase in the scope of judicial review, which formerly had been exercised chiefly in cases reviewing issues of federalism.

A more interesting comparison than the degree of activism in the respective judiciaries is the difference in the way the judicial function is perceived. Some precepts accepted in the United States as essential to the judicial function are not applicable at all to the Canadian judiciary. For example, the judiciary in Canada is explicitly given reference jurisdiction and the ability to render advisory opinions. Reference of questions can be made by the federal cabinet (which also appoints the judges). By contrast, advisory opinions are prohibited by the U.S. Constitution's limitation of "the judicial power of the United States" to "cases and controversies."23 Moreover, the opinions of the judiciary are not invariably final in Canada-they may be but one step in a decisionmaking process that also involves other branches of the central government, or even the provinces; in the United States, by contrast, courts are constitutionally incapacitated from deciding cases unless their decisions will be final. ${ }^{24}$ When a Supreme Court pronouncement is subject to veto by the executive and legislative branches, or merely expresses an opinion not necessary to decision of a concrete case, it is not within the judicial power and is an unconstitutional advisory opinion. ${ }^{25}$

The most extreme example of the opposite doctrine in Canada is the override clause in the 1982 Canadian Charter adopting an approach that is contrary to anything in the U.S. constitutional scheme or experience. ${ }^{26}$ The

regulating in an area not delegated to Congress but intended to be left to the states. Wingo, $11 \mathrm{Vt} \mathrm{L}$ Rev at $\mathbf{4 7 6}$ (cited in this note).

Wingo does not consider, however, that judicial willingness to analyze legislative motivation, as well as protecting state power in this way, could also detract from it. There is no reason to believe that a court accustomed to second-guessing legislative of purposes would stop at questions of allocation of legislative powers; state legislation that is reviewed, for example, in civil liberties cases, would presumably also be subject to that more searching inquiry-even legislation not involving race or "fundamental rights," which are already subject to more searching "strict scrutiny" review. The Canadian inquiry into the dominant character of legislation in order to evaluate its constitutionality has traditionally been limited to questions of federalism and not individual rights simply because until 1982 Canada's Constitution did not protect individual rights, and judicial review accordingly was mostly confined to questions of federalism.

22. Can Const (Constitution Act, 1982) pt I (Canadian Charter of Rights and Freedoms), ch 11 , $\S 15$.

23. US Const, Art III. Canada's comparatively broad rules of standing, and its range of remedies, which is broader than is customary in the United States, may be products of its broad conception of what is justiciable.

24. To some extent, this strictly stated requirement of finality confronts questions of degree; of course the Congress or a state legislature can overturn a judicial rule by enacting a regulatory statute that is not unconstitutional.

25. Hayburn's Case, 2 US (2 Dallas) 409 (1792).

26. Canadian Charter \& 33 . 
Canadian Charter allows provincial legislatures to override constitutional decisions. They can provide that a particular law applies for a five-year period notwithstanding the Charter. There is a sunset clause, but the legislature can renew its override at the end of the five-year period. A province can insulate its law from a finding of unconstitutionality by providing in the law's preamble that it applies notwithstanding the Charter. It can also reenact the provision and override five years later.

The override applies in areas of fundamental freedoms, legal rights, and antidiscrimination. ${ }^{27}$ The override procedure was adopted to resolve a political impasse over the adoption of the Charter. It was thought it would be politically costly for provinces to use the override, and thus its use would be minimal. In this spirit, Manitoba early said it would not use the override. ${ }^{28}$ The principal user has been Quebec, which has used the clause to back off the Charter, saying Quebec is subject only to the Quebec Charter of Rights and not to the 1982 Charter, to which Quebec did not consent. ${ }^{29}$

In the United States, such an override scheme would be contrary both to rules about the finality of judicial decisions and to federal supremacy. In Martin $v$. Hunter's Lessee, ${ }^{30}$ the state of Virginia sought independence from U.S. Supreme Court rulings, and that position was seen as a fundamental challenge to our federal scheme. In Canada, however, this override scheme, combined with Supreme Court review of provincial law, carries some elements of giving the provinces the last word on national law, while giving the national system the last word on provincial!

Canada has no separation of powers doctrine as we know it; in the United States, of course, separation of powers, together with federalism, is at the root of our basic governmental structure. In Canada, courts can perform "nonjudicial functions," and nonjudicial entities can exercise judicial power. Indeed, in Canada, the courts are part of the negotiating process and seem less separate from other branches of government than U.S. courts are.

The override scheme that Canada has adopted can be seen as an example of various branches and levels of government working out solutions through compromise rather than principle. Similarly, the Canadian Supreme Court can be seen as playing a negotiating role in the decisions in the early $1980 \mathrm{~s}$ about how the Constitution could be amended, decisions resulting in the adoption of the 1982 Charter. In 1981, the Supreme Court ruled in response to references made by three provinces that a "substantial degree" of provincial consent was required to amend the Constitution. ${ }^{31}$ Subsequently

27. The following subjects are not, however, subject to override: democratic rights, mobility rights, language rights, the enforcement provision of the Charter, and the sexual equality clause (even though other substantive equality rights, such as freedoms of conscience and religion, expression, association, and the media are subject to override). Canadian Charter $\$ 33$.

28. Paul Weiler, Rights and Judges in a Democracy-A New Canagdian Version, 18 U Mich J L. Ref 51 (1984).

29. Peter W. Hogg, Constitutional Law of Canada 69 (Carswell, 2d ed 1985).

30. 14 US (1 Wheaton) 304 (1816).

31. Re: Opposition to a Resolution to Amend the Constitution, [1981] l SCR 753. 
the federal-provincial agreement of November 1981 was passed by the provincial legislatures, signed by all premiers except the Premier of Quebec, then passed by both houses of Parliament, and transmitted to the U.K. Parliament, which enacted it. In the meantime, Quebec directed a second reference, asking directly whether its consent was necessary for the proposed amendments. The Quebec Court of Appeal and the Supreme Court of Canada both answered that Quebec's consent was unnecessary. ${ }^{32}$

In many ways, the most basic theme about Canadian governmental structure, including federalism, in relation to that of the United States, is that there is a less-felt need in Canada for separation of functions or clear definition of boundaries. While Canada's provinces do have a separate legislative sphere, in contrast to the states in the U.S. system, in all other ways the Canadian system has significantly less separation of functions than our own. Not only do national courts review provincial laws, but the central government participates in the appointment and compensation of most provincial judges. Provincial governors also are appointed by the national executive and are removable for cause by him or her. The Senate is also controlled by the Governor General through appointment of each senator and one speaker, a process that may affect the Senate's concern with national issues more than regional ones. Moreover, the Constitution gives the national government the power of disallowance, that is, the power to disallow any provincial legislation within a year of its passage, even legislation involving subjects delegated to the provinces. The power may exist in theory only (today it is not used), but its recognition in the Constitution shows a contemplation of intermixing functions, both between the judiciary and the other branches and between the provinces and the national government.

In short, both the law and the institutions of the Canadian provinces are less separate and independent than the law and institutions of the U.S. states. Indeed, the only separation in the Canadian system is in the legislative spheres of power of the national government and the provinces-the one type of separation that the U.S. Constitution, as interpreted, fails to create.

Moreover, the Canadian style of decisionmaking is more one of working things out through negotiation and compromise than one of finding the "right answer" to each problem or having one authoritative decisionmaker. Negotiation is a dominant form of the exercise of power in Canada, including negotiation between the central and the provincial governments. This practice in some ways treats the provinces like separate sovereigns whose consent must be obtained. Indeed, a primary forum for governmental decisionmaking in Canada is "executive federalism," whereby disputed issues are resolved through meetings and negotiations between the different levels of government. ${ }^{33}$ Instead of dealing with economic problems on a

32. Re: Objection to a Resolution to Amend the Constitution, [1982] 2 SCR 793.

33. In the United States, there is nothing comparable to Canada's executive federalism. It may be that the existence of an executive that is responsible to the legislature (the parliamentary system), in contrast to the U.S. separation of powers between executive and legislature, makes executive 
nationwide basis through federal legislation, as the U.S. Congress does, Canada deals with these and other important and sensitive matters through negotiation, principally at federal-provincial conferences. This may be accomplished at special ad hoc conferences, or at conferences between the prime minister and the premiers, or at a departmental or ministerial level. The aim of each conference is to achieve mutual agreement-sometimes only between one of the provinces and the national government, or sometimes more broadly-on some problem(s) that gave rise to the conference. Negotiated agreement is what the conference must produce to be successful, but no agreement on theoretical underpinnings is required.

The Canadian attitude was well summed up by Pierre Trudeau when he congratulated the framers of the Canadian Constitution for "its absence of principles, ideas, or other frills ...."34 In general, the Canadian attitude is that legalisms and legal analysis are less important than political flexibility, "cooperative federalism," negotiation and adjustment, and sharing of power. ${ }^{35}$ The United States resembles Canada in that it is not bound by the original understanding of its Constitution's composers. But unlike Canada, the U.S. power structure is based on legalisms, on a carefully worked-out hierarchy of rights, and not on practical stances like bargaining and compromise, to work out the bounds of central and state/provincial power.

\section{V \\ Conclusion}

In both the United States and the Canadian systems (unlike many other constitutional systems), there is judicial supremacy, but the systems are organized in different ways. Canada recognizes far more legislative power in the provinces, as a matter of constitutional law, than the United States does in its states (although through congressional inaction the states are in fact allowed to exercise many powers of government). There is no provincial law in Canada that is protected in the sense that state law is protected in the United States, because in Canada common law is national, the only provincial law is statutory, and the statutes are subject to interpretation by the Canadian Supreme Court. Moreover, there are provisions, although in desuetude, allowing the national government to reject unsatisfactory provincial laws, through the powers of reservation and disallowance. In some senses, then,

federalism possible and helpful for Canada but impossible in the United States. After all, even if all the U.S. governors did agree on a position, or negotiated with the White House a particular compromise arrangement, who is to say their agreement would be accepted by state legislatures or by Congress?

34. Pierre Trudeau, Federalism, Nationalism and Reason, in Paul-André Crepeau \& C.B. Macpherson, eds, The Future of Canadian Federalism 16, 29 (U Toronto Press, 1965).

35. One reason for practical considerations to predominate in Canada is that it does not have an autochthonous constitution: In theory, the Parliament of the United Kingdom has the power to declare the Dominion experiment a mistake and repeal the Canadian constitution. With such a legal backdrop, it is not surprising that the theoretical locus of power should seem less important and relevant to Canadians than the practical locus of power. 
the provinces seem less supreme than the U.S. states. We next find, however, that after Canada's Supreme Court finds a law unconstitutional, that decision is subject to override by popular vote in any province. The judiciary is not accepted as the final arbiter, nor is the federal system. Several aspects of the Canadian system, such as the lack of independent state law and the existence of nonbinding judicial constitutional pronouncements, would be unthinkable in the United States federal system, yet seem to work successfully in Canada.

Enough has been said to show that the Canadian experience raises some questions about many of our suppositions in the United States about what a federal system necessarily entails. Federalism has many forms; moreover, the form a government adopts is not much controlled by its constitution's language or intent. Comparison of the U.S. system with Canada's also shows the United States does have strong states' rights, in some respects, stronger than those of its neighbor to the north, even though the provinces are generally considered more powerful vis-vis their national government than the U.S. states. 